\title{
The students' career choice and job preparedness strategies: A social environmental perspective
}

\author{
Md. Roknuzzaman Siddiky, Shahanaz Akter \\ Department of Sociology, Noakhali Science and Technology University, Noakhali, Bangladesh
}

\begin{tabular}{l} 
Article Info \\
\hline Article history: \\
Received Oct 1, 2020 \\
Revised Mar 10, 2021 \\
Accepted Apr 13, 2021 \\
\hline
\end{tabular}

Keywords:

Career choice

Career planning

Job preparedness

Social environmental career theory

\begin{abstract}
The study aimed to investigate the factors determining the students' career choice and find out their job preparedness strategies. Moreover, the study sought to propose a theory which could explain the students' career choice from a social environmental perspective. Primary data for this study were collected from 120 students selected from fourteen academic departments of the Noakhali Science and Technology University (NSTU) in Bangladesh based on snow-ball sampling. The study revealed that several factors involving students' family preferences, teachers' advice, job prestige, job security, remunerations, scope of promotion, scope of pension, scope of professional development, personal interests, academic majors, educational attainments and career development trainings have significant association with the students' career decision-making. However, gender and social class did not have significant effects on the students' career choice. The study proposed a career choice theory which indicates that the students' career choice and career preferences are not determined by their personal interests alone; rather they are determined by the interplay of several social, cultural and economic forces. The study indicated that the majority of the respondents undertake self-study to pursue their preferred jobs. While career development trainings play an important role in developing the competencies of the students for jobs, a majority of the respondents do not have such trainings. As such, the study suggested that the students of the NSTU should undertake career development courses as a strategy for job preparedness. Finally, the study suggested that the NSTU should set up a career guidance and counseling cell to link their students with the current labor market.
\end{abstract}

This is an open access article under the CC BY-SA license.

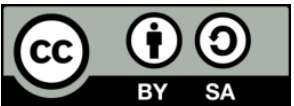

\section{Corresponding Author:}

Md. Roknuzzaman Siddiky

Department of Sociology

Noakhali Science and Technology University

Noakhali-3814, Bangladesh

Email: rokonsiddiky@hotmail.com

\section{INTRODUCTION}

Higher education plays an important role in the socio-economic development of a country. Institutions for higher education are factories which manufacture skilled human resources through imparting, creating and disseminating knowledge and providing advanced education in a wide range of areas which result in the increase of productivity, business earnings and economic growth and thus are critical for socioeconomic development of Bangladesh like other ones. As such, the universities are the generators of knowledge and students are the most important part of this process. Nevertheless, after graduation, one of the most important problems that a student face is to choose his suitable career which is defined as the sequence of a person's several roles and work experiences over time [1], [2]. However, most of the public and private 
universities of Bangladesh do not have career guidance or counseling programs that could link their students with labor market [3].

Hence, the students usually choose their careers without having proper knowledge about career information and labor market conditions. However, a successful career mostly depends on a careful career planning which involves making career choice or career decision about which career path and job are to pursue among the available alternatives rationally and undertaking the proper strategies for career readiness. If a student is not careful about his career and proceeds haphazardly, he may not accomplish his desired career aspiration and achieve successes in his career. Therefore, career planning plays an important role in building students' successful careers via making their suitable career choices and undertaking necessary strategies to accomplish their career aspirations.

However, career choices are not determined by the students' own interests alone, a number of factors are also involved. In other words, career choice is not determined by one single factor, rather it is determined by the interplay of a number of factors. According to the social cognitive career theory (SCCT), the students' career choices are determined by the interaction of three variables which are self-efficacy, outcome expectations and personal goals [4], [5]. Self-efficacy denotes an individual's personal beliefs about his or her capabilities to carry out particular behaviors or course of actions. Outcome expectations are beliefs about the consequences or outcomes of performing particular behaviors. Thus, outcome expectations pertaining to particular job could be tangible rewards or better working conditions. However, personal goals incorporate one's intention to engage in certain activity or to produce a particular outcome [4], [5]. According to the SCCT, when a person thinks that he is competent enough to perform a particular activity and expects that activity to produce valued outcome, he is likely to develop interests in that activity. Therefore, self-efficacy, outcome expectations, and career-related interests cultivate particular educational and occupational choice goals. As such, the SCCT looks at the development of career goals and choices as a function of the interplay among self-efficacy, outcome expectations and interests over time. However, personal interests may be constrained by several social and cultural factors including lack of support, social barriers and cultural beliefs [4], [5].

In contrast, the social learning theory (SLT) was developed by a group of American researchers [6][8]. According to this theory, four factors influence career decision-making. These are genetic endowment, environmental conditions, learning experiences, and task-approach skills. Genetic endowment involves those aspects of individual which are in-built and inherited such as gender, race, color, intelligence, special abilities, and so on. Environmental conditions involve the complex of several social, cultural, economic, technological and environmental factors such as the effects of family, teachers and resources, technology, training opportunities, occupational factors, labor market, and so on. The environmental conditions are usually beyond the individual control affecting a person's career decision-making. Learning experiences may involve instrumental learning and associative learning that have effects on career choice. Task approach skills are learning skills, goal setting, obtaining occupational information, and so on which are important in career decision-making. The SLT maintains that an individual makes a career decision based on the observations about self-relating to his or her interests and abilities or capabilities, and about environment, especially the generalizations about the world of work [9].

While these two theories carry much significance to examine the students' career decision-making, social environmental perspective has not yet been properly highlighted in the academic world. A number of studies are available in the academia focusing on investigating the factors affecting students' career choices or plans. Adams [10] suggests that several variables including parents' or relatives' advice, talents, skills and abilities, business opportunities, employment security, potential for personal growth and development have significant effects on students' career choice. Saleem, et al. [11] indicate that students' parent's occupation, media and personal interests have effects on their career selection. Cavus, Geri, and Turgunbayeva [12] claim that the dignity of profession, economic factors, personal characteristics and skills, university and current developments are the important factors affecting career plans and choice of the students.

Korkmaz [13] shows that gender, school type, parents' educational level, and family income have significant effects on students' career choices. Mtemeri [14] asserts that family members, especially parents' influence, peers' advice and encouragement, and schools have effects on students' career choices. Nyamwange [15] argues that the student' interests are significant in determining their career choice. Kazi and Akhlaq [16] put forward that parents' influence, peers' influence, gender, financial reasons and personal interest have significant effects on students' career choices. Al-Abri and Kooli [17] indicate that financial benefits and personal interests have significant influence on students' career decision. Humayon, et al. [18] opine that family influence, personal interest and economic considerations have powerful effect on students' career choices. Jiang [19] opines that a person's career plans and decision are influenced by his self-analysis and objective assessment of environment. Osi [20] claims that socio-economic status has significant effect on students' career choice while gender and the type of school do not have such effects on their choice. While 
the available studies are important, narrow focus has been paid so far in order to investigate the factors determining the students' career choices, and the strategies that they undertake to accomplish their career goals. Moreover, no broad empirical study has been conducted so far in Bangladesh context so as to find out the factors influencing the students' career decision-making and find out the strategies or actions adopted by them to pursue their preferred jobs. As such, the study is intended to investigate the factors determining the career choice of the students of a public university in Bangladesh and find out their job preparedness strategies to pursue their preferred jobs. In this regard, the study also seeks to propose a theory in order to examine the students' career decision-making taking into account a social environmental perspective.

\section{RESEARCH METHOD}

\subsection{Research design and respondents}

The study was conducted in view of the intention and convenience of the researchers in Noakhali Science and Technology University (NSTU) - a public university located in the district of Noakhali of Bangladesh. The study was a sample survey for which fourteen academic departments were purposively chosen. A total of 120 respondents were selected from the students who were studying at undergraduate final and master's levels at fourteen academic departments of the NSTU on the basis of snow-ball sampling. The socio-demographic characteristics of the respondents in terms of five variables such as respondents' departments or academic majors, gender, academic year, age and social class are presented in Table 1.

Table 1. Socio-demographic characteristics of the respondents

\begin{tabular}{|c|c|c|c|}
\hline Variables & & Frequency & Percent $(\%)$ \\
\hline \multirow{15}{*}{ Departments (academic Majors) } & A. Math & 8 & 6.7 \\
\hline & ACCE & 8 & 6.7 \\
\hline & AGRI & 10 & 8.3 \\
\hline & BGE & 8 & 6.7 \\
\hline & CSTE & 7 & 5.8 \\
\hline & DBA & 11 & 9.2 \\
\hline & $\mathrm{EEE}$ & 7 & 5.8 \\
\hline & ENG & 8 & 6.7 \\
\hline & ESDM & 14 & 11.7 \\
\hline & FIMS & 9 & 7.5 \\
\hline & FTNS & 8 & 6.7 \\
\hline & ICE & 8 & 6.7 \\
\hline & OCEAN & 6 & 5.0 \\
\hline & STAT & 8 & 6.7 \\
\hline & Total & 120 & 100.0 \\
\hline \multirow{4}{*}{ Gender } & Male & 69 & 57.5 \\
\hline & Female & 51 & 42.5 \\
\hline & Total & 120 & 100.0 \\
\hline & Fourth year & 79 & 65.8 \\
\hline \multirow[t]{2}{*}{ Academic year } & Master's & 41 & 34.2 \\
\hline & Total & 120 & 100.0 \\
\hline \multirow{2}{*}{ Age } & Mean & Median & $\mathrm{SD}$ \\
\hline & 23.31 & 23.00 & .754 \\
\hline \multirow{4}{*}{ Social class } & Lower middle class & 11 & 9.2 \\
\hline & Middle class & 91 & 75.8 \\
\hline & Upper middle class & 18 & 15.0 \\
\hline & Total & 120 & 100.0 \\
\hline
\end{tabular}

Source: Fieldwork, August, 2020

As shown in Table 1, a majority of the respondents belonged to the environmental science and disaster management (ESDM) department (11.7\%), followed by the business administration (DBA) department $(9.2 \%)$, the agriculture (AGRI) department $(8.3 \%)$, and the fisheries and marine science (FIMS) department $(7.5 \%)$. However, the applied mathematics (A. Math) department, the applied chemistry and chemical engineering (ACCE) department, the biotechnology and genetic engineering (BGE) department, the English (ENG) department, the food technology and nutrition science (FTNS) department, the information and communication engineering (ICE) department, and the statistics (STAT) department each shares $6.7 \%$ of the respondents. Each of the computer science and telecommunication engineering (CSTE) department and the electrical and electronic engineering (EEE) department shares $5.8 \%$ of the total respondents. However, the oceanography (OCEAN) department shares only $5.0 \%$ of the respondents. It is evident that a majority $(57.5 \%)$ of the respondents were males while $42.5 \%$ of the respondents were females. A large majority (about $66 \%$ ) of the respondents were the students of Fourth year while roughly $34 \%$ of the respondents were 
the students of Master's. The respondents' mean age is 23.31 years whereas their median age is 23.00 years. As can be seen, a large majority (about 76\%) of the respondents belonged to middle class while $15 \%$ and roughly $9 \%$ of the respondents belonged to upper middle class and lower middle class respectively.

\subsection{Measurement and data collection tools}

Most of the items were measured on an ordinal scale, especially a 5-point Likert scale. The scale was defined from very negative to very positive order of magnitude. On the scale, 1 indicated not at all, 2 indicated slightly, 3 indicated moderately, 4 indicated much, and 5 indicated very much. The study employed both types of data - primary and secondary. Primary data were collected from the respondents through telephone interview conducted by the researchers themselves from August 10, 2020 to August 25, 2020 by using a structured questionnaire. In contrast, secondary data were obtained from various relevant secondary sources including relevant books, journal articles, dissertations, and conference papers.

\subsection{Data analysis techniques}

Primary data were analyzed by using frequency distributions, percentages and central tendency. Because of the ordinal character of data, the study reasonably used median to measure the extent to which the students considered several social, cultural and economic factors in making their career choice [21]. Chisquare $\left(\mathrm{x}^{2}\right)$ test was used to find out the significance of association between students' career choice and several selected independent variables which were students' gender, social class, academic majors, family preferences, teachers' advice, job status, job security, the remuneration from job, the scope of promotion, the scope of professional development, the scope of pension, their personal interests, educational attainments and career development trainings. The study tried to validate the following research hypotheses as in Table 2.

Table 2. Research hypotheses and null hypotheses

\begin{tabular}{|c|c|c|c|}
\hline No. & Research hypotheses $\left(\mathrm{H}_{\mathrm{a}}\right)$ & Null hypotheses $\left(\mathrm{H}_{0}\right)$ & Statistical test \\
\hline 2 & $\begin{array}{l}\text { There is an association between the students' career } \\
\text { choice and their social class }\end{array}$ & $\begin{array}{l}\text { There is no association between the students' career } \\
\text { choice and their social class }\end{array}$ & Chi-square \\
\hline 3 & $\begin{array}{l}\text { There is an association between the students' career } \\
\text { choice and their academic departments/majors }\end{array}$ & $\begin{array}{l}\text { There is no association between the students' career } \\
\text { choice and their academic departments/majors }\end{array}$ & Chi-square \\
\hline 4 & $\begin{array}{l}\text { There is an association between the students' career } \\
\text { choice and their family preferences }\end{array}$ & $\begin{array}{l}\text { There is no association between the students' career } \\
\text { choice and their family preferences }\end{array}$ & Chi-square \\
\hline 6 & $\begin{array}{l}\text { There is an association between the students' career } \\
\text { choice and job prestige }\end{array}$ & $\begin{array}{l}\text { There is no association between the students' career } \\
\text { choice and job prestige }\end{array}$ & Chi-square \\
\hline 7 & $\begin{array}{l}\text { There is an association between the students' career } \\
\text { choice and job security }\end{array}$ & $\begin{array}{l}\text { There is no association between the students' career } \\
\text { choice and job security }\end{array}$ & Chi-square \\
\hline 8 & $\begin{array}{l}\text { There is an association between the students' career } \\
\text { choice and the remuneration from job }\end{array}$ & $\begin{array}{l}\text { There is no association between the students' career } \\
\text { choice and the remuneration from job }\end{array}$ & Chi-square \\
\hline 11 & $\begin{array}{l}\text { There is an association between the students' career } \\
\text { choice and the scope of pension in the job }\end{array}$ & $\begin{array}{l}\text { There is no association between the students' career } \\
\text { choice and the scope of pension in the job }\end{array}$ & Chi-square \\
\hline 12 & $\begin{array}{l}\text { There is an association between the students' career } \\
\text { choice and their personal interests }\end{array}$ & $\begin{array}{l}\text { There is no association between the students' career } \\
\text { choice and their personal interests }\end{array}$ & Chi-square \\
\hline 13 & $\begin{array}{l}\text { There is an association between the students' career } \\
\text { choice and their educational attainments }\end{array}$ & $\begin{array}{l}\text { There is no association between the students' career } \\
\text { choice and their educational attainments }\end{array}$ & Chi-square \\
\hline 14 & $\begin{array}{l}\text { There is an association between the students' career } \\
\text { choice and their career development trainings }\end{array}$ & $\begin{array}{l}\text { There is no association between the students' career } \\
\text { choice and their career development trainings }\end{array}$ & Chi-square \\
\hline
\end{tabular}

\section{RESULTS AND DISCUSSION}

\subsection{Results}

Table 3 shows the students' career choice and career preferences. Career choice involves an important decision about which career path a student will pursue in the course of his live in view of comparative advantages and labor market conditions while career preferences or options involve important decisions about which specific professions or jobs the students will pursue in view of their relative importance.

Int J Eval \& Res Educ, Vol. 10, No. 2, June 2021: 421 - 431 
Table 3. Career choice and career preferences of the students

\begin{tabular}{cccc}
\hline Variables & & Frequency & Percent $(\%)$ \\
\hline Students' career choice & To join public sector & 81 & 67.5 \\
& To join private sector & 39 & 32.5 \\
Students' career preferences & Total & 120 & 100.0 \\
& BCS & 38 & 31.7 \\
& Public banks & 12 & 10.0 \\
& Private banks & 7 & 5.8 \\
& Private/multinational companies & 13 & 10.8 \\
& Public research/scientific organizations & 20 & 16.7 \\
& Private research/scientific organizations & 11 & 9.2 \\
& Others & 19 & 15.8 \\
\hline Source: Fieldwork & Total & 120 & 100.0
\end{tabular}

Source: Fieldwork, August, 2020

As shown in Table 3, a large majority $(67.5 \%)$ of the respondents reported that they intend to join public sector while $32.5 \%$ of the respondents reported that they intend to join private sector after their completion of study. It is found that a majority (31.7\%) of the respondents intend to join Bangladesh Civil Service (BCS), followed by public research/scientific organizations (16.7\%), the others $(15.8 \%)$, private/multinational companies $(10.8 \%)$, public banks $(10.0 \%)$, private research/scientific organizations $(9.2 \%)$, and finally, private banks $(5.8 \%)$. This is noteworthy that the others involve jobs in both public and private sectors including teaching professions in universities, IT and power related jobs.

Table 4 describes the factors that the students consider in making their career choices in view of comparative advantage and labor market conditions. Put differently, Table 4 shows the extent to which the students consider several factors such as family preferences, teachers' advice, job prestige, job security, remuneration from job, the scope of promotion in job, the scope of professional development in job, the scope of pension in job, their personal interests and educational attainments in making their career choice.

Table 4. The factors that the students consider in making their career choice

\begin{tabular}{|c|c|c|c|c|c|}
\hline No. & Measurement instruments/ indicators & Mean & Median & SD & Rating \\
\hline 1 & $\begin{array}{l}\text { The extent to which the students consider family preferences in making their career } \\
\text { choice }\end{array}$ & 3.63 & 3.00 & .788 & Moderately \\
\hline 2 & $\begin{array}{l}\text { The extent to which the students consider teachers' advice in making their career } \\
\text { choice }\end{array}$ & 4.28 & 4.00 & .724 & Much \\
\hline 3 & The extent to which the students consider job prestige in making their career choice & 4.10 & 4.00 & .782 & Much \\
\hline 4 & The extent to which the students consider job security in making their career choice & 4.24 & 4.00 & .879 & Much \\
\hline 5 & $\begin{array}{l}\text { The extent to which the students consider the remuneration from the job in making } \\
\text { their career choice }\end{array}$ & 3.75 & 3.00 & .872 & Moderately \\
\hline 6 & $\begin{array}{l}\text { The extent to which the students consider the scope of promotion in the job in making } \\
\text { their career choice }\end{array}$ & 4.35 & 4.00 & .644 & Much \\
\hline 7 & $\begin{array}{l}\text { The extent to which the students consider the scope of professional development in } \\
\text { the job in making their career choice }\end{array}$ & 4.47 & 5.00 & .721 & Very much \\
\hline 8 & $\begin{array}{l}\text { The extent to which the students consider the scope of pension in the job in making } \\
\text { their career choice }\end{array}$ & 3.82 & 4.00 & 1.167 & Much \\
\hline 9 & $\begin{array}{l}\text { The extent to which the students consider their personal interests in making their } \\
\text { career choice }\end{array}$ & 4.44 & 4.00 & .499 & Much \\
\hline 10 & $\begin{array}{l}\text { The extent to which the students consider their educational attainments in making } \\
\text { their career choice }\end{array}$ & 4.07 & 4.00 & .725 & Much \\
\hline
\end{tabular}

Note: $1=$ not at all; $2=$ slightly; $3=$ moderately; $4=$ much; $5=$ very much

As illustrated in Table 4, the students consider family preferences moderately in making their career choice since the median value is 3.00 on a 5-point Likert scale. However, the students consider teachers' advice much in making their career choice (median=4.00). The students consider job prestige or dignity much in making their career choice (median=4.00). The students consider job security much in making their career choice (median=4.00). However, the students consider the remuneration from the job moderately in making their career choice (median=3.00). As can be seen in Table 4, the students consider the scope of promotion in the job much in making their career choice (median=4.00). The students consider the scope of professional development in the job very much in making their career choice (median=5.00). The students consider the scope of pension in the job much in making their career choice (median=4.00). The students consider their personal interests much in making their career choice (median=4.00). Finally, it is evident that the students consider their educational attainments much in making their career choice (median=4.00).

Table 5 illustrates the hypotheses testing results summary which describes whether there is a significant association between the students' career choice and the fourteen independent variables. As noted 
earlier, the independent variables involve students' gender, social class, academic departments/majors, family preferences, teachers' advice, job prestige, job security, the remuneration from the job, the scope of promotion in the job, the scope of professional development in the job, the scope of pension in the job, students' personal interests, educational attainments and career development trainings.

Table 5. Hypotheses testing results summary

\begin{tabular}{|c|c|c|c|c|c|}
\hline No. & Research hypothesis $\left(\mathrm{H}_{\mathrm{a}}\right)$ & Chi-value $\left(\mathrm{x}^{2}\right)$ & df & Alpha-value & p-value \\
\hline 1 & $\begin{array}{l}\text { There is an association between the students' career choice and } \\
\text { their gender }\end{array}$ & 1.987 & 1 & 0.05 & .159 \\
\hline 2 & $\begin{array}{l}\text { There is an association between the students' career choice and } \\
\text { their social class }{ }^{* * *}\end{array}$ & .422 & 2 & 0.05 & .810 \\
\hline 3 & $\begin{array}{l}\text { There is an association between the students' career choice and } \\
\text { their academic departments/majors }\end{array}$ & 26.087 & 13 & 0.05 & .017 \\
\hline 4 & $\begin{array}{l}\text { There is an association between the students' career choice and } \\
\text { their family preferences }{ }^{*}\end{array}$ & 14.734 & 3 & 0.01 & .002 \\
\hline 5 & $\begin{array}{l}\text { There is an association between the students' career choice and } \\
\text { their teachers' advice* }\end{array}$ & 10.502 & 2 & 0.01 & .005 \\
\hline 6 & $\begin{array}{l}\text { There is an association between the students' career choice and } \\
\text { job prestige }\end{array}$ & 83.719 & 3 & 0.01 & .000 \\
\hline 7 & $\begin{array}{l}\text { There is an association between the students' career choice and } \\
\text { job security }\end{array}$ & 88.415 & 3 & 0.01 & .000 \\
\hline 8 & $\begin{array}{l}\text { There is an association between the students' career choice and } \\
\text { the remuneration from the job* }\end{array}$ & 90.731 & 2 & 0.01 & .000 \\
\hline 9 & $\begin{array}{l}\text { There is an association between the students' career choice and } \\
\text { the scope of promotion in the job* }\end{array}$ & 56.182 & 2 & 0.01 & .000 \\
\hline 10 & $\begin{array}{l}\text { There is an association between the students' career choice and } \\
\text { the scope of professional development in the job }\end{array}$ & 6.056 & 2 & 0.05 & .048 \\
\hline 11 & $\begin{array}{l}\text { There is an association between the students' career choice and } \\
\text { the scope of pension in the job }\end{array}$ & 106.860 & 3 & 0.01 & .000 \\
\hline 12 & $\begin{array}{l}\text { There is an association between the students' career choice and } \\
\text { their personal interests }\end{array}$ & 13.109 & 1 & 0.01 & .000 \\
\hline 13 & $\begin{array}{l}\text { There is an association between the students' career choice and } \\
\text { their educational attainments }\end{array}$ & 59.751 & 2 & 0.01 & .000 \\
\hline 14 & $\begin{array}{l}\text { There is an association between the students' career choice and } \\
\text { their career development trainings }{ }^{* *}\end{array}$ & 10.554 & 4 & 0.05 & .032 \\
\hline
\end{tabular}

${ }^{*}$ Significant at $99 \%$ confidence level; ${ }^{* *}$ Significant at $95 \%$ confidence level; ${ }^{* * *}$ Statistically not significant

As shown in Table 5, the empirical evidence failed to support the research hypothesis that there is an association between the students' career choice and their gender $\left(\mathbf{x}^{2}=1.987 ; \mathrm{df}=1 ; \mathrm{p}\right.$-value $\left.>0.05\right)$. Moreover, the empirical evidence failed to support the research hypothesis that there is an association between the students' career choice and their social class $\left(\mathbf{x}^{2}=.422 ; \mathrm{df}=2 ; \mathrm{p}\right.$-value $\left.>0.05\right)$. However, the empirical evidence supported the research hypothesis that there is an association between the students' career choice and their academic departments/majors $\left(\mathbf{x}^{2}=26.087 ; \mathrm{df}=13 ; \mathrm{p}\right.$-value $\left.<0.05\right)$. The empirical evidence validated the research hypothesis that there is an association between the students' career choice and their family preferences $\left(\mathbf{x}^{2}=14.734 ; \mathrm{df}=3 ; \mathrm{p}\right.$-value $\left.<0.01\right)$. The empirical evidence supported the research hypothesis that there is an association between the students' career choice and their teachers' advice $\left(\mathbf{x}^{2}=10.502 ; \mathrm{df}=2 ; \mathrm{p}\right.$ value $<0.01)$.

The empirical evidence validated the research hypothesis that there is an association between the students' career choice and job prestige $\left(\mathbf{x}^{2}=83.719 ; \mathrm{df}=3 ; \mathrm{p}\right.$-value $\left.<0.01\right)$. The empirical evidence supported the research hypothesis that there is an association between the students' career choice and job security $\left(\mathbf{x}^{2}=88.415 ; \mathrm{df}=3 ; \mathrm{p}\right.$-value $\left.<0.01\right)$. The empirical evidence supported the research hypothesis that there is an association between the students' career choice and the remuneration from the job $\left(\mathbf{x}^{2}=90.731 ; \mathrm{df}=2\right.$; p-value $<0.01)$. The empirical evidence validated the research hypothesis that there is an association between the students' career choice and the scope of promotion in the job $\left(\mathbf{x}^{2}=56.182 ; \mathrm{df}=2 ; \mathrm{p}\right.$-value $\left.<0.01\right)$. The empirical evidence validated the research hypothesis that there is an association between the students' career choice and the scope of professional development in the job $\left(\mathbf{x}^{2}=6.056 ; \mathrm{df}=2 ; \mathrm{p}\right.$-value $\left.<0.05\right)$. The empirical evidence validated the research hypothesis that there is an association between the students' career choice and the scope of pension in the job $\left(\mathbf{x}^{2}=06.860 ; \mathrm{df}=3 ; \mathrm{p}\right.$-value $\left.<0.01\right)$. The empirical evidence supported the research hypothesis that there is an association between the students' career choice and their personal interests $\left(\mathbf{x}^{2}=13.109 ; \mathrm{df}=1 ; \mathrm{p}\right.$-value<0.01). The empirical evidence also supported the research hypothesis that there is an association between the students' career choice and their educational attainments $\left(\mathbf{x}^{2}=59.751\right.$; $\mathrm{df}=2$; $\mathrm{p}$-value $<0.01)$. Finally, it is observed that that there is a significant association between the students' career choice and their career development trainings $\left(\mathbf{x}^{2}=10.554 ; \mathrm{df}=4\right.$; $\mathrm{p}$-value $\left.<0.05\right)$. 
Table 6 shows the strategies for job preparedness of the students. Job preparedness or readiness strategies have been measured by three variables involving the students' career development trainings or courses, their principal mode of study for job preparation, and hours of daily study to pursue their preferred jobs.

Table 6. The students' job preparedness strategies

\begin{tabular}{cccc}
\hline Variables & & Frequency & Percent $(\%)$ \\
\hline Career development trainings & None & 52 & 43.3 \\
& English language course & 11 & 9.2 \\
& Computer training & 19 & 15.8 \\
& Both English and computer trainings & 14 & 11.7 \\
Principal mode of study & Others & 24 & 20.0 \\
& Total & 120 & 100.0 \\
& Coaching & 6 & 5.0 \\
Hours of daily study & Group study & 5 & 4.2 \\
& Self-study & 91 & 75.8 \\
& Both group and self-studies & 18 & 15.0 \\
& Total & 120 & 100.0 \\
& $0-2$ hours & 32 & 26.7 \\
& $2-4$ hours & 56 & 46.7 \\
& $4-6$ hours & 26 & 21.7 \\
\hline
\end{tabular}

Source: Fieldwork, August, 2020

As shown in Table 6, the majority (43.3\%) of the respondents said that they have not undertaken any career development training or course to pursue their preferred jobs. $20 \%$ of the respondents have pursued other courses related to career development, followed by computer training (nearly 16\%), both English and computer trainings (11.7\%), and English language course (roughly 9\%). It is evident that with regard to principal mode of study for job preparation, the vast majority (nearly 76\%) of the respondents stated that they mainly take up self-study for job preparation, followed by both group and self-studies $(15 \%)$, coaching (5\%), and group study (roughly 4\%). A majority (46.7\%) of the respondents stated that they study 2-4 hours daily while $26.7 \%$ of the respondents stated that they study $0-2$ hours daily for job. $21.7 \%$ of the respondents said that they study 4-6 hours daily while only $5 \%$ of the respondents said that they study $6-8$ hours a daily for job.

\subsection{Discussion}

The study reveals that public sector is the students' main career choice compared to private sector. Among the professions of public sector, BCS is the most popular among the students of the NSTU followed by public research/scientific organizations and public banks. However, among the professions of private sector, private/multinational companies are the most preferred among the students followed by private research/scientific organizations and private banks. The study indicates that the students consider teachers' advice, job prestige, job security, the scope of promotion, the scope of pension, their personal interests and educational attainments much in choosing their careers while they consider family preferences and the remuneration from job moderately and consider the scope of professional development in the job very much in making their career choice. The study reveals that public sector's jobs are preferred among the students mainly due to job prestige, job security, the scope of promotion, and the scope of pension. This finding is in line with the findings presented by several studies [22]-[24]. However, the private sector's jobs are preferred among the students mainly due to the scopes of better remuneration and professional development. This finding is consistent with the findings indicated by Jarkiewicz, Massey and Brown [25]; Rashid and Rashid [26].

The study indicates that students' career choice is significantly associated with several independent variables such as their academic departments/majors, family preferences, teachers' advice, job prestige, job security, the remuneration from job, the scope of promotion in job, the scope of professional development in job, the scope of pension in job, their personal interests, educational attainments and career development trainings while the other variables such as gender and social class do not have significant association with the students' career choice. Hence, the findings of the study on the whole are consistent with findings put forward by a number of studies [7], [10], [14], [17], [18]. While the study is in line with the finding presented by Osi [20] that gender does not have significant effect with students' career choice, the study is not consistent with his finding that socio-economic status has significant influence on their career choice. While the findings on the whole are consistent with the findings presented by Kazi and Akhlaq [16], the study negates their finding in that gender has significant effect in choosing career. With regard to the mode of study 
for job preparedness, the study reveals that self-study still is the most widespread among the students. Based on the two career choice theories discussed earlier and our empirical evidence, we put forward a theory from a social environmental perspective [4]-[8]. The theory we term as the 'Social Environmental Career Theory' (SECT) describing the linkage between the students' career choice and social environment which is illustrated in Figure 1.

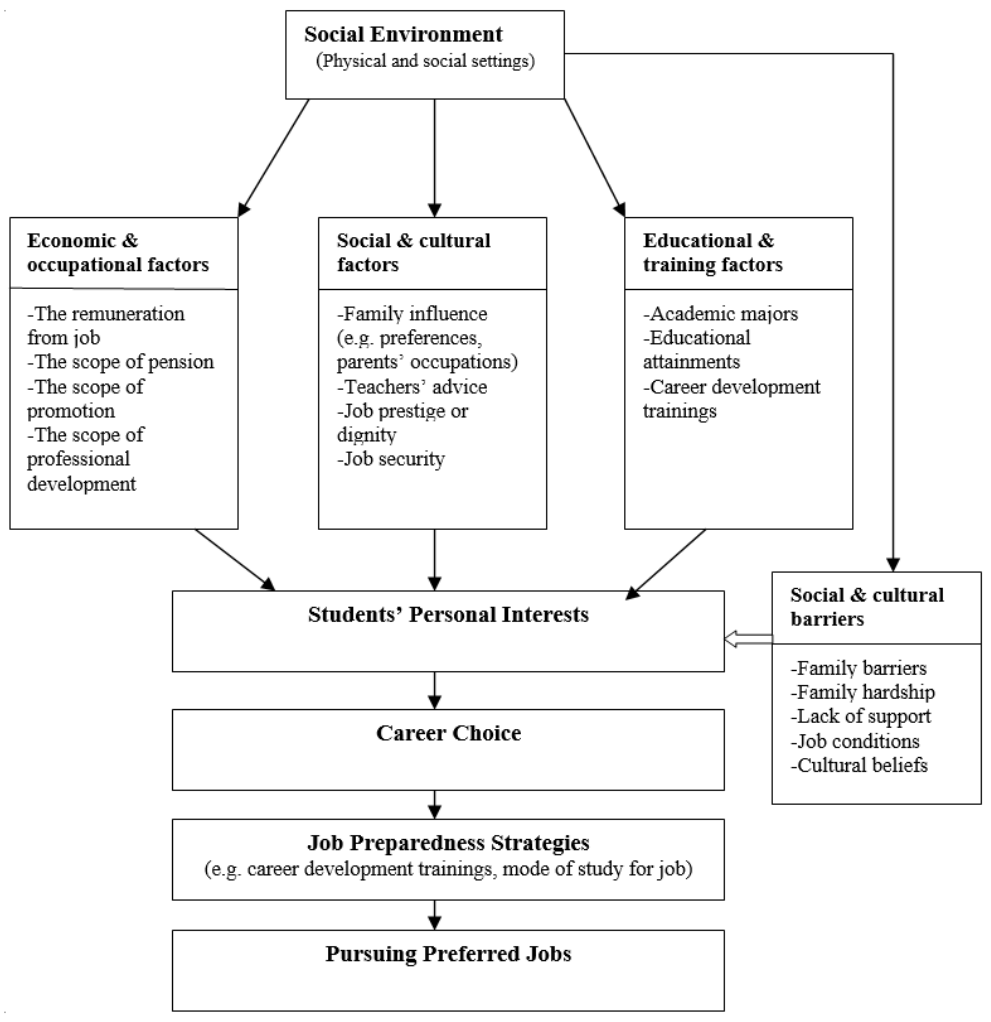

Figure1. The social environmental career theory

As shown in Figure 1, social environment is the complex of physical and social settings, in which people live, grow, develop their personalities and become socialized. As Barnet and Casper [27] state, social environments involve the immediate physical surroundings, social relationships, and cultural settings within which defined groups of people function and interact. As such, in the social setting, people's actions and behaviors are influenced and constrained by several social, cultural, economic forces. Hence, there is a duality in the nature of social, cultural and economic forces. Some social, cultural and economic forces facilitate personal actions and behaviors while some social, cultural and economic forces constrain them. As such, the students' career choices are not determined by their personal interests alone. A number of factors are also involved. Usually these factors are economic and occupational factors, social and cultural factors, and educational and training factors.

The social and cultural factors mainly involve family influence (e.g. preferences and parents' occupations), teachers' advice, job prestige or dignity, and job security. The students' personal interests in certain career may be influenced by their family preferences and teachers' advice consciously or unconsciously. Moreover, the students' career choice and career development may be influenced by their parents' occupations [11], [28]. On the other hand, the students come to know about the prestige, dignity and security involved in certain jobs through interaction with several community people as well as through mass media and thereby develop their personal interests in such jobs. The economic and occupational factors usually are the remunerations or financial benefits from job, the scope of promotion, the scope of pension, and the scope of professional development which involves the advancement of professional expertise and professional ethics. Through social interaction, observation and labor market information, the students learn the comparative advantages or material benefits of certain jobs in terms of remuneration, the scope of promotion, the scope of pension, and the scope of professional development. The students make objective 
assessment of several material conditions of a number of alternative jobs available in labor market through social learning, in particular via socialization process. Thus, the students' personal interests in certain jobs are influenced by several economic and occupational factors.

Moreover, the students' personal interests are also influenced by the educational and training factors such as their academic majors, educational attainments and career development trainings. While these factors are mainly personal, are shaped by the influence of social, cultural and economic factors. Educational attainments and career development trainings of the students allow them to develop their self-efficacies, especially the personal beliefs about their abilities to perform certain jobs [4], [5]. Moreover, the students can make self-assessment whether they are fit for their preferred jobs or not. However, the students' personal interests and career choice may be constrained by several social and cultural barriers which are inherent in society [4], [5], [29]. These barriers may be family barriers, family hardship, job conditions, cultural beliefs, and so on. Once the students' career choice and preferences are determined, they take on several job preparedness strategies including undertaking career development trainings and selecting mode of study to pursue their preferred jobs. However, like career choice, the students' job preparedness strategies are also influenced by several social, cultural and economic factors. Hence, the SECT is consistent with the SCCT proposed by Lent, et al. [4], Lent [5]. Like the SCCT, the SECT indicates that the students' personal interests, career choices and career preferences are facilitated and constrained by several social, cultural and economic factors in a social setting.

The SECT is also supported by the SLT [6]-[8], in those personal interests and career choices are determined by the interaction of several social and environmental forces. The SECT recognizes that the students make self-analysis and objective assessment of environmental conditions in order to make their career decisions. As such, this statement is in line with the statements made by both the SCCT [4], [5] and SLT [6]-[8] as well as made by Jiang [19] and Zhang [30]. While the study is consistent with the findings put forward by $\mathrm{Su}$, et al. [31] in that career decision-making is influenced by the students' personal factors and group factors including self-efficacy and parental influence, they have not examined the students' career choice by highlighting the interplay of several social, cultural and economic factors within a social context. While the study is supported by the findings presented by Theresa [32] in that parental influence plays an important role in deciding students' career choice, her findings have ignored the role of various social, cultural and economic factors and their interaction within social environment in determining students' career decision-making.

\section{CONCLUSION}

The paper reveals that the public sector is mostly preferred choice among the students to develop their careers because of several material benefits including job prestige or dignity, job security and the scope of pension. The study indicates that several variables such as family preferences, teachers' advice, job prestige or dignity, job security, the remuneration, the scope of promotion, the scope of pension, the scope of professional development, students' personal interests, academic majors, educational attainments, and career development trainings have significant association with the career decision-making. As such, the study opines that such factors have effects on determining the students' career choice. With regard to the students' career decision- making, the study proposes a theory known as 'the SECT' which indicates that the students' career choice and career preferences are not determined by their personal interests alone, rather they are determined by the interplay of several social, cultural and economic forces which are the social and cultural factors, the economic and occupational factors, and the educational and training factors. However, the students' personal interests and career choice may be constrained by several social and cultural factors including family hardship, job conditions and cultural beliefs. While the career development training programs play a vital role in developing the skills and competencies of the students, a majority of the respondents do not have such trainings to prepare themselves for jobs.

As such, the paper suggests that the students of the NSTU should undertake career development courses or trainings as a strategy for job preparedness. The paper proposes that the students of the NSTU should involve themselves in diverse co-curricular and extra-curricular activities so as to develop their soft skills that could support them in their career development process. The students should also involve themselves in various social networks and educational activities in order to widen the scope of their learning pertaining to career planning and development in the social environment. In this regard, there is an urgent need for setting up a career guidance and counseling cell in all private and public universities in Bangladesh including the NSTU for providing the students with necessary information about career development and present labor market conditions and thereby linking them with current labor market. Finally, the paper recognizes the need for undertaking a further study, especially a qualitative study in order to find out more detailed information regarding students' career decision-making by applying in-depth-study. 


\section{ACKNOWLEDGEMENTS}

The authors are thankful to Prof. Dr. Newaz Mohammad Bahadur, the respected Dean of the Faculty of Educational Sciences of the NSTU, for his heartfelt encouragement to undertake this study. The authors extend their thankfulness to Prof. Dr. Mohammed Faruque Uddin, the honorable Treasurer of the NSTU, and the faculty members of the Department of Sociology for their sincere motivations throughout the research work. The authors are also thankful to all the participants who were involved in this research work.

\section{REFERENCES}

[1] M.B. Arthur, D.T. Hall, and B.S. Lawrence, "Generating new directions in career theory: the case for transdisciplinary approach,” in M.B. Arthur, D.T. Hall, and B.S. Lawrence, Eds., Handbook of career theory. New York: The Cambridge University Press, 1989, pp. 7-25.

[2] Career Development Institute, "Definition: career development and related roles," 2017. [Online]. Available: https://www.thecdi.net/write/CDI_Definitions_FINAL.pdf

[3] A.K.Z. Ahmed, L. Ferdous, and A.M. Sharif, "Career counselling at the university: Bangladesh scenario," European Scientific Journal, vol. 13, no. 28, pp. 381-393, 2017.

[4] R.W. Lent, S.D. Brown, and G. Hackett, "Social cognitive career theory," in D. Brown and Associates, Eds., Career choice and development. San Francisco: Jossey-Bass, 2002, pp. 255-311.

[5] R.W. Lent, "A social cognitive of career development and counselling," in S.D. Brown and R.T. Lent, Eds., Career development and counselling. New Jersey: Wiley, 2005, pp. 101-127.

[6] J.D. Krumboltz, "Improving career development theory from a social learning perspective," in M.L. Savickas and R. W. Lent, Eds., Convergence in Career Development Theories. Palo Alto, CA: Consulting Psychologists Press, 1994, pp. 9-32.

[7] L.K. Mitchell and J.D. Krumboltz, "Krumboltz's learning theory of career choice and counselling," in D. Brown and Associates, Eds., Career Choice and Development. San Francisco: Jossey-Bass, 1996, pp. 255-311.

[8] R.S. Sharif, Apply career development theory to counselling. Pacific Grove, CA: Brooks/Cole, 1997.

[9] M. Ireh, "Career development theories and their implications for high school career guidance and counselling," The High School Journal, vol. 83, no. 2, pp. 24-40, 2000

[10] G. Adams, "The factors that influence career choice" Master's Thesis, The University of the Western Cape, Cape Town, South Africa, 2014. [Online]. Available: http://etd.uwc.ac.za/xmlui/handle/11394/4671

[11] N. Saleem, M.A. Hanan, I. Saleem, and R.M. Shamshad, "Career selection: role of parent's profession, mass media and personal choice," Bulletin of Education and Research, vol. 36, no. 2, pp. 25-37, 2014.

[12] S. Cavus, S. Geri, and K. Turgunbayeva, "Factors affecting the career plans of university students after graduation," International Journal of Humanities and Social Science, vol. 5, no. 5, pp. 94-99, 2015.

[13] H. Korkmaz, "Factors influencing students' career chooses in science and technology: Implications for high school curricula," Procedia-Social and Behavioral Sciences, vol. 197, pp. 966-972, Jul. 2015, doi: 10.1016/j.sbspro.2015.07.284.

[14] J. Mtemeri, "Factors influencing the choice career pathways among high school students in Midlands Province," Thesis, University of South Africa, Pretoria, South Africa, 2015.

[15] J. Nyamwange, "Influence of student's interest on career choice among fist year university students in public and private universities in Kisii County, Kenya," Journal of Education and Practice, vol. 7, no. 4, pp. 96-102, 2016.

[16] A.S. Kazi and A. Akhlaq, "Factors affecting students career choice," Journal of Research and Reflections in Education, vol.11, no. 2, pp.186-196, 2017.

[17] N. Al-Abri and C. Kooli, "Factors affecting the career path choice of graduates: a case of Omani," International journal of Youth Economy, vol. 2, no. 2, pp. 105-117, 2018, doi: 10.18576/ijye/020203.

[18] A.A. Humayon, S. Raza, R. Khan, and N. Ansari, "Effect of family influence, personal interest and economic considerations on career choice amongst undergraduate students in higher educational institutions of Vehari Pakistan," International Journal of Organizational Leadership, vol. 7, no. 2, pp. 129-142, 2018.

[19] J. Jiang, "Research on the necessity of career planning education for freshmen," Advances in Social Science, Education and Humanities Research, vol. 300, pp. 575-578, 2018, doi: 10.2991/erss-18.2019.114

[20] P. Osi, "Factors responsible for career choice among secondary school students in Ogba Egbema Ndoni local government area, Rivers State," International Journal of Education and Evaluation, vol. 4, no.7, pp. 26-31, 2018.

[21] F. C. Nachmias, and D. Nachmias, Research methods in the social sciences. New York: Worth Publishers, 2008.

[22] M. A. Hossan, "Factors affecting switching job from private university to public university in Bangladesh," European Journal of Business and Management, vol. 9, no. 26, pp. 56-63, 2017.

[23] L. Nahar, A. Hossain, A. Rahman, and A. Bairagi, "The relationship of job satisfaction, job stress, mental health of government and non-government employees of Bangladesh," Psychology, vol. 4, no. 6, pp. 520-525, 2013, doi: 10.4236/psych.2013.46074.

[24] P.K. Padhy and J. Bhuyan, "Determinant of job satisfaction in public and private sector: an empirical study," International journal of Engineering Technology, Management and Applied Sciences, vol. 3, no.1, pp. 70-81, 2015.

[25] C. L. Jarkiewicz, T.K. Massey, and R.G. Brown, "Motivations in public and private organizations: a comparative study," Public Productivity and Management Review, vol. 21, no. 3, pp. 230-250, 1998.

[26] S. Rashid and U. Rashid, "Work motivation differences between public and private sector," American International Journal of Social Science, vol. 1, no. 2, pp. 24-33, 2012. 
[27] E. Barnett and M. Casper, "A definition of social environment," American Journal of Public Health, vol. 91, no. 3, pp. 465-467, 2001.

[28] M. Viola and N. Daniel, "Influence of parental occupation on career development of youths with intellectual disabilities in selected skills training institutions in Zambia," International Journal of Humanities Social Sciences and Education, vol. 6, no. 1, pp. 66-74, 2019.

[29] P. Cardoso, and J.F. Marques, "Perception of career barriers: gender and ethnic variables," International Journal of Educational and Vocational Guidance, vol. 8, pp. 49-61, 2008, doi: 10.1007/s10775-008-9135-y.

[30] T. Zhang, "A study on career planning guidance for college students from the perspective of enterprises," Paper presented at the 6th International Conference on Social Network, Communication and Education (SNCE 2016), 2016, doi: 10.2991/snce-16.2016.3.

[31] M.S. Su, T.C. Chang, C.C. Wu, and C.W. Liao, "Factors affecting the student career decision-making of junior high school students," International Journal of Information and Education Technology, vol. 6, no. 11, pp. 843-850, 2016.

[32] L.W. Theresa, "Factors that inform students' choice of study and career," Journal of Education and Practice, vol. 6, no. 27, pp. 43-49, 2019. 